\title{
Faux pas atpažinimo ir Happé keistų istorijų testų lietuviškų versijų adaptacija bei psichometrinių savybių vertinimas
}

\section{A. Jasionis* \\ G. Jasionyte் $\dot{e}^{* *}$ \\ R. Mameniškiené*}

*Vilniaus universitetas, Medicinos fakultetas, Neurologijos centras

**Vilniaus universitetas, Medicinos fakultetas

\begin{abstract}
Santrauka. İvadas. Vienas pagrindinių socialinių pažintinių funkcijų posričių - minčių teorija (MT) - apima gebejjimą suprasti kitų žmonių mintis, ketinimus, emocijas ir numatyti jų elgesį. MT deficitas yra būdingas daugeliui neurologinių ir psichikos sutrikimų. Iki šiol nebuvo MT ištyrimo testų, adaptuotų lietuviškai kalbančiai populiacijai.

Tikslas. Išversti ir atlikti kalbinę bei kultūrinę dviejų MT testų - Faux pas atpažinimo testo ir Happé keistų istorijų testo - adaptaciją lietuviškai kalbančiai populiacijai ir įvertinti jų psichometrines savybes.

Tiriamieji ir tyrimo metodai. Abu testai buvo išversti iš anglų kalbos į lietuvių ir iš lietuvių į anglų kalbą. Naudojant lietuviškus testų variantus, ištirta 100 pilnamečių asmenų. Patikrintas testų patikimumas ir matavimų pagrịstumas. Vidinis nuoseklumas vertintas apskaičiuojant Cronbach $\alpha$ koeficientą, vertinimo patikimumas - intraklasinị koreliacijos koeficientą, o konvergentinis konstrukcijos patikimumas - Spearman koreliacijos koeficientą.

Rezultatai. Apskaičiuota Faux pas atpažinimo testo faux pas istorijų Cronbach $\alpha$ koeficiento reikšmé buvo 0,815 , kontrolinių istorijų - 0,426, o Happé keistų istorijų testo - 0,708. Faux pas atpažinimo testo faux pas istorijų intraklasinio koreliacijos koeficiento reikšmè buvo 0,996, o Happé keistų istorijų testo - 0,911. Apskaičiuota silpna teigiama statistiškai reikšminga koreliacija tarp Happé keistų istorijų testo ir Faux pas atpažinimo testo faux pas istorijų îvertinimų ( $\mathrm{r}=0,355, \mathrm{p}=0,045)$, tačiau Faux pas atpažinimo testo kontrolinių istorijų ịverčiai statistiškai reikšmingai nekoreliavo su faux pas istorijų $(r=0,033, p=0,745)$ ir Happé keistų istorijų testo $(r=0,109, p=0,282)$ rezultatais. Abiejų testų išorinis ir turinio pagrịstumas buvo ịrodyti.

Išvados. Faux pas atpažinimo testas ir Happé keistų istorijų testas pritaikyti lietuviškai kalbančiai populiacijai. Abu instrumentai gali būti naudingi vertinant socialines pažintines funkcijas.
\end{abstract}

Raktažodžiai: minčių teorija, socialinès pažintinès funkcijos, Faux pas atpažinimo testas, Happé keistų istorijų testas.

\section{IVADAS}

Dėmesys, atmintis ir mokymasis, kalba, suvokimo, vykdomosios ir socialinès funkcijos yra pagrindinès pažintinių funkcijų sritys [1]. Socialinės pažintinès funkcijos padeda

\author{
Adresas: \\ Arminas Jasionis \\ Vilniaus universitetas, Medicinos fakultetas, \\ Neurologijos centras \\ Santariškiu g. 2, LT-08661 Vilnius \\ El.paštas arminas.jasionis@santa.lt
}

apdoroti ir interpretuoti gautą socialinę informaciją bei suvokti aplinkinių asmenų vidinę psichinę būseną [2]. Tai būtinas visaverčio socialinio funkcionavimo elementas, kuriam sutrikus blogėja gyvenimo kokybè, psichinė sveikata, įsidarbinimo galimybės [3, 4].

Vienas pagrindinių socialinių pažintinių funkcijų posričių - minčių teorija (MT) (angl. Theory of mind) - apima gebejjimą suprasti kitų žmonių mintis, ketinimus, emocijas ir numatyti jų elgesị $[5,6]$. Išskiriamos dvi MT rūšys: pažintinė, atsakinga už ịsitikinimu, minčių suvokima, ir afektinè, igalinanti suprasti emocijas ir jausmus [7]. MT tinklo, apimančio migdolinị kūną (lot. corpus amygdaloideum),

(C) Neurologijos seminarai, 2020. Open Access. This article is distributed under the terms of the Creative Commons Attribution 4.0 International License CC-BY 4.0 (http://creativecommons.org/licenses/by/4.0/), which permits unrestricted use, distribution, and reproduction in any medium, provided you give appropriate credit to the original author(s) and the source, provide a link to the Creative Commons license, and indicate if changes were made. 
temporoparietalinę jungtị (angl. temporoparietal junction), medialinę prefrontalinę žievę (angl. medial prefrontal cortex) bei kitas galvos smegenų sritis, pažeidimas sutrikdo socialines pažintines funkcijas [8]. MT deficitas būdingas autizmui, Aspergerio sindromui, depresijai, šizofrenijai, Parkinsono ligai, frontotemporalinei demencijai, Alzheimerio ligai, epilepsijai ir kitiems neurologiniams bei psichikos sutrikimams [9-13].

Objektyviam MT funkcijų sutrikimui įvertinti reikalingi standartizuoti instrumentai. Pažintinė MT vertinama atliekant klaidingo įsitikinimo užduotis (angl. False-belief tasks), kuriose naudojamos paveikslèliais iliustruotos istorijos. Tikrinama, ar asmuo geba suprasti, kad veikëjas neteisingai ịsitikinęs (pirmos eilès klaidingas ịsitikinimas) arba klysta, interpretuodamas kito veikejjo ịsitikinimus (antros eilès klaidingas ịsitikinimas) [14]. Afektinė MT paprastai vertinama atliekant „Emocijų atpažinimo iš akių“" testą (angl. Reading the Mind in the Eyes test), kuriuo tikrinamas gebejjimas suprasti psichinę būseną iš žvilgsnio, pateikiant nespalvotas akių srities nuotraukas [15]. Kompleksiškam MT funkcijų įvertinimui dažniausiai naudojami Faux pas atpažinimo testas (angl. Faux Pas Recognition test) ir Happé keistų istorijų testas (angl. Strange stories test) $[16,17]$. Siekiant, kad ịvertinimas būtų tikslus, instrumentai turi atitikti reikalingus psichometrinius reikalavimus ir būti pritaikyti tiriamajai populiacijai, t. y. derètų su kultūriniu kontekstu. Mūsų žiniomis, kol kas nèra lietuviškai kalbančiai populiacijai adaptuotų MT funkcijų ištyrimo testų, todèl šio darbo tikslas buvo dažniausius užsienio autorių naudojamus, t. y. Faux pas atpažinimo testą ir Happé keistų istorijų testą, pritaikyti lietuvių kalbai.

\section{DARBO TIKSLAS}

Išversti ir atlikti kalbinę bei kultūrinę dviejų MT testų Faux pas atpažinimo ir Happé keistų istorijų - adaptaciją lietuviškai kalbančiai populiacijai, ịvertinti jų tinkamumą socialinėms pažintinėms funkcijoms tirti.

\section{TIRIAMIEJI IR TYRIMO METODAI}

\section{Instrumentai (skalès)}

Faux pas atpažinimo testą 1999 m. sukūrè Baron-Cohen ir bendraautoriai. Jis skirtas vertinti faux pas (netyčinio, socialiai nepriimtino, dažniausiai kitą asmenị ịžeidžiančio veiksmo ar teiginio) suvokimo funkciją. Ši funkcija susiformuoja 9-11 gyvenimo metais [16, 18]. Testu vertinama tiek pažintinė, tiek afektinė MT [16]. Testą sudaro 20 istorijų - 10 su faux pas ir 10 kontrolinių, kuriose faux pas nèra. Perskaičius kiekvieną istoriją, paklausiama, ar, tiriamojo nuomone, kas nors pasakẻ kažką netinkamo. Jei atsakoma teigiamai, užduodami septyni papildomi klausimai (1 pav.). Pirmieji du (1-2) klausimai vertina, ar tiriamasis atpažino faux pas. Trečias klausimas tikrina netinkamumo supratimą (kodèl tai nėra tinkama), ketvirtas - veikejjo ketinimų supratimą (ar tiriamasis supranta, kodèl veikejjas tai pasakè), penktas - veikèjo įsitikinimų supratimą (ar tiriamasis supranta, kokie faktai veikejjui žinomi), šeštas - empatiją (ar tiriamasis supranta, kaip veikèjas galètų jaustis). Paskutiniai du (7-8) klausimai yra kontroliniai ir tikrina, ar tiriamasis teisingai suprato istoriją. Jei tiriamasis faux pas neatpažino (neigiamai atsakè į pirmą klausimą), užduodami tik kontroliniai klausimai.

Vertinant istorijas su faux pas, už 1-6 klausimus skiriama 0 arba 1 taškas. Už kontrolinius klausimus taškai neskiriami, tačiau, atsakius neteisingai, daroma prielaida, kad tiriamasis nesuprato istorijos, ir ji nevertinama. Už vieną faux pas istoriją galima surinkti nuo 0 iki 6 taškų. Bendras dešimties faux pas istorijų ịvertinimas svyruoja nuo 0 iki 60 taškų. Taip pat vertinamos atskiros sritys: faux pas atpažinimas (pirmieji du klausimai, 0-20 taškų), netinkamumo supratimas (trečias klausimas, 0-10 taškų), ketinimų supratimas (ketvirtas klausimas, 0-10 taškų), įsitikinimų supratimas (penktas klausimas, 0-10 taškų) ir empatija (šeštas klausimas, 0-10 taškų). Vertinant kontrolines istorijas, kiekviena teisingai atmesta istorija vertinama 2 taškais. Už neteisingą faux pas priskyrimą kontrolinei istorijai duodama 0 taškų. Bendras dešimties kontrolinių istorijų icvertinimas gali svyruoti nuo 0 iki 20 taškų.

Happé keistų istorijų testu taip pat tiriamos abi MT sritys. Originalią testo versiją sudaro 24 istorijos: 8 mentalistinès, 8 fizinès ir 8 tarpusavyje nesusijusių sakinių ištraukos [17]. Tyrime naudotos tik mentalistinès istorijos, kadangi įrodyta, kad tik šiai testo daliai atlikti reikalinga mentalizacija, t. y. gebẻjimas suprasti kitų psichinę būseną [19]. Perskaičius kiekvieną istoriją, užduodamas vienas klausimas apie veikẻjų veiksmų motyvus. Tikimasi, kad tiriamasis pastebès ir ịvardins netiesiogiai pateiktą melą, dvigubą blefavimą, apgaulę, ịtikinèjimą, „baltą“ melą ar 
Simonas mėgsta meluoti. Simono brolis Mantas žino, kad jis beveik niekada nesako tiesos. Vakar Simonas paėmė brolio stalo teniso raketę. Mantas žino, kad Simonas ją kažkur paslèpė, tačiau negali jos rasti. Mantas labai susierzino, nuėjo pas Simoną ir paklausė: „Kur mano stalo teniso raketė? Tu ją paslëpei arba spintoje, arba po savo lova, nes visur kitur aš išieškojau. Kur ji? Spintoje ar po lova?" Simonas atsakè, kad raketė yra po lova.

Klausimas. Kodėl Mantas raketės ieškos spintoje?

2 pav. Viena iš Happé keistų istorijų, iliustruojanti melą

klaidingą veikèjų įsitikinimą ( 2 pav.). Teisinga interpretacija vertinama 2 , dalinis priežasčių paaiškinimas - 1 , nespecifinès informacijos akcentavimas - 0 taškų, todèl iš viso surenkama nuo 0 iki 16 taškų [17].

\section{Testų vertimas ir adaptacija}

Pirmiausia vertejjas, kurio gimtoji kalba yra lietuvių, abu testus išvertè iš anglų ị lietuvių kalbą. Veikèjų vardai, valiutos, matavimo vienetų, įstaigų pavadinimai buvo pakeisti, kad atitiktų lietuvišką kontekstą. Pirminius testų variantus vertejjas, kurio gimtoji kalba yra anglų, tačiau gerai mokantis lietuvių kalbą, išvertè į anglų kalbą. Ekspertų komisija, sudaryta iš neurologo, psichologo ir vertejo, išanalizavo neatitiktis ir parenge pradinę testo versiją. Bandomojo testavimo, kurị atliko 10 pilnamečių asmenų, metu išanalizuota, ar visos istorijos ir klausimai yra suprantami, suderinami su lietuvių kultūra. Nutarus, kad abu testai atitinka šiuos reikalavimus ir nuo originalo skiriasi tik minètomis modifikacijomis, parengti galutiniai Faux pas atpažinimo testo ir Happé keistų istorijų testo variantai lietuvių kalba.

\section{Duomenų rinkimas}

Paaiškinus darbo tikslą, užtikrinus konfidencialumą ir gavus rašytinius informuoto asmens sutikimus, Vilniaus universiteto Medicinos fakultete atliktas 100 asmenų testavimas. Tiriamieji - vyresni nei 18 metų asmenys, kurių gimtoji kalba yra lietuvių. Tiriamieji dalyvauti pakviesti dalijantis neformaliu pranešimu internete. Neitraukimo kriterijai - bloga klausa, intelektinè negalia, prastai moka lietuvių kalbą - nenustatyti né vienam atvykusiam asmeniui. Dalyviai buvo tiriami po vieną. Tyrejjas garsiai skaitè visas Faux pas atpažinimo testo ir Happé testo istorijas, po kiekvienos iš jų užduodamas atitinkamus klausimus. Tiriamasis galejo pasitikrinti istorijos detales jam duotoje kopijoje. Tiriamujų atsakymus netaisyta kalba tyrèjas registravo popierinèje formoje. Ištyrus visus dalyvius, du tyrejjai atskirai atliko visų tiriamųjų testų įvertinimą. Tyrimui atlikti gautas regioninio bioetikos komiteto leidimas.

\section{Psichometrinès testų savybės}

Svarbiausios tyrimų instrumentų charakteristikos yra patikimumas ir matavimų pagrịstumas.

Testo patikimumas (angl. reliability) atspindi rezultatų pastovumą, kai instrumentas naudojamas kelis kartus pa- našiomis sąlygomis. Testų patikimumas tikrinamas įvertinus vidini nuoseklumą (angl. internal consistency), t. y. atsakymų i klausimus koreliaciją, ir vertinimo patikimumą (angl. inter-rater reliability), t. y. koreliaciją tarp dviejų tyrejjų vertinimų [20].

Matavimų pagrịstumas (angl. validity) apibūdina, kaip testas atitinka savo paskirti, t. y. ar vertina būtent tas charakteristikas, kurias siekiama ištirti. Buvo ịvertintas išorinis (angl. face), turinio (angl. content) ir konvergentinis konstrukcijos (angl. construct) pagrịstumas. Išorinis pagrịstumas rodo, kad visi klausimai yra aiškūs, suprantami, nereikalingu klausimų nèra. Turinio pagrịstumas detaliau analizuoja, ar visas testas yra logiškas, apima visas tiriamos srities dimensijas. Šiems kriterijams vertinti statistinė analizè netaikoma. Konvergentinis konstrukcijos pagristumas rodo, ar testo rezultatai reikšmingai koreliuoja su kito instrumento, tiriančio teoriškai panašias charakteristikas, matavimais [20].

\section{Statistinis duomenų apdorojimas}

Duomenys apdoroti IBM SPSS 23.0 programa. Apskaičiuoti duomenų vidurkiai, standartiniai nuokrypiai. Vidinis nuoseklumas vertintas apskaičiuojant Cronbach $\alpha$ koeficientą, kuris laikytas pakankamai geru, kai reikšmė $\geq 0,70$. Vertinimo patikimumas matuotas intraklasiniu koreliacijos koeficientu (angl. intraclass correlation coefficient), kuris laikytas pakankamai geru, kai reikšmė $\geq 0,75$. Kiekybinių duomenų normalumas tikrintas Kolmogorovo-Smirnovo testu. Visi kiekybiniai kintamieji neatitiko normaliojo skirstinio, todèl, lyginant dviejų nepriklausomų grupių kintamuosius, naudotas Mann-Whitney U testas, o lyginant daugiau nei dviejų nepriklausomų grupių kintamuosius, - Kruskal-Wallis H testas. Kiekybinių kintamujuc koreliacija vertinta apskaičiuojant Spearman koreliacijos koeficientą; koreliacija laikyta silpna, kai koeficientas yra 0,3-0,5, vidutinio stiprumo - 0,5-0,7, stipria 0,7-0,9, labai stipria - $\geq 0,9$. Laikyta, kad skirtumas tarp lyginamųjų grupių statistiškai reikšmingas, kai p reikšmė $<0,05$.

\section{REZULTATAI}

Ištirta 100 asmenų: 63 moterys ir 37 vyrai. Tiriamųjų amžius - nuo 18 iki 60 metų (vidurkis - 30,66 $\pm 11,32$ metų). 36 asmenys turèjo vidurinị išsilavinimą, 7 - aukštajị neuniversitetinị, 57 - aukštajị universitetinị.

Bendri testų rezultatai pateikti 1 lentelèje. Nė vienas tiriamasis negavo maksimalaus Faux pas atpažinimo testo faux pas istorijų įvertinimo (FP). Daugiausia surinkta 58 taškai (6 asmenys), mažiausiai - 12 (3 asmenys). Maksimalų Faux pas atpažinimo testo kontrolinių istorijų įvertinimą (FP kontr.) - 20 taškų - surinko net 49 tiria- 
1 lentelè. Testų ịvertinimų vidurkiai, intervalai ir testų vidinis nuoseklumas

\begin{tabular}{||c|c|c|c|c||}
\hline & Vidurkis \pm SN & Intervalas & Teorinis intervalas & Cronbach $\alpha$ \\
\hline FP & $41,25 \pm 14,49$ & $12-58$ & $0-60$ & 0,815 \\
\hline FP kontr. & $18,68 \pm 1,54$ & $14-20$ & $0-20$ & 0,426 \\
\hline Happé & $13,67 \pm 1,77$ & $10-16$ & $0-16$ & 0,708 \\
\hline
\end{tabular}

SN - standartinis nuokrypis, FP - Faux pas atpažinimo testo faux pas istorijų įvertinimas, FP kontr. - Faux pas atpažinimo testo kontrolinių istorijų ịvertinimas, Happé - Happé keistų istorijų testo įvertinimas

2 lentelè. Faux pas atpažinimo testo atskirų istorijų ịvertinimas

\begin{tabular}{||c|c|c|c|c|c|}
\hline \multicolumn{3}{|c|}{ Faux pas istorijos } & \multicolumn{3}{c|}{ Kontrolinės istorijos } \\
\hline Istorijos nr. & $\begin{array}{c}\text { Teisingas faux pas } \\
\text { aptikimas, } \mathbf{n}\end{array}$ & Tašku vidurkis \pm SN & Istorijos nr. & $\begin{array}{c}\text { Teisingas faux pas } \\
\text { atmetimas, n }\end{array}$ & Tašku vidurkis \pm SN \\
\hline 2 & 97 & $5,17 \pm 1,29$ & 1 & 93 & $1,86 \pm 0,51$ \\
\hline 4 & 90 & $5,11 \pm 1,86$ & 3 & 100 & $2,00 \pm 0,00$ \\
\hline 7 & 73 & $4,14 \pm 2,62$ & 5 & 93 & $1,86 \pm 0,51$ \\
\hline 11 & 83 & $4,67 \pm 2,19$ & 6 & 87 & $1,74 \pm 0,68$ \\
\hline 12 & 76 & $4,26 \pm 2,47$ & 8 & 92 & $1,84 \pm 0,55$ \\
\hline 13 & 31 & $1,86 \pm 2,79$ & 9 & 85 & $1,70 \pm 0,72$ \\
\hline 14 & 79 & $4,74 \pm 2,46$ & 10 & 100 & $2,00 \pm 0,00$ \\
\hline 15 & 88 & $4,24 \pm 1,82$ & 17 & 97 & $1,94 \pm 0,34$ \\
\hline 16 & 67 & $3,98 \pm 2,81$ & 19 & 100 & $2,00 \pm 0,00$ \\
\hline 18 & 55 & $3,08 \pm 2,85$ & 20 & 87 & $1,74 \pm 0,68$ \\
\hline
\end{tabular}

SN - standartinis nuokrypis

3 lentelè. Happé keistų istorijų testo atskirų istorijų ịvertinimai

\begin{tabular}{||c|c|c|c|c|c||}
\hline \hline Istorijos nr. & Psichinės būsenos taikinys & Gauta 0 taškų, n & Gautas 1 taškas, n & Gauti 2 taškai, n & Taškų vidurkis \pm SN \\
\hline 1 & Melas & 7 & 23 & 70 & $1,63 \pm 0,61$ \\
\hline 2 & Dvigubas blefavimas & 3 & 6 & 91 & $1,88 \pm 0,41$ \\
\hline 3 & Apgaule & 0 & 55 & 45 & $1,45 \pm 0,50$ \\
\hline 4 & Itikinėjimas & 3 & 29 & 68 & $1,65 \pm 0,54$ \\
\hline 5 & „Baltas“ melas & 0 & 8 & 92 & $1,92 \pm 0,27$ \\
\hline 6 & „Baltas“ melas & 0 & 28 & 72 & $1,72 \pm 0,45$ \\
\hline 7 & Klaidingas įsitikinimas & 0 & 38 & 62 & $1,62 \pm 0,49$ \\
\hline 8 & Klaidingas įsitikinimas & 7 & 6 & 87 & $1,80 \pm 0,55$ \\
\hline
\end{tabular}

$\mathrm{SN}$ - standartinis nuokrypis

4 lentelè. Testų ịvertinimų skirtumai, priklausomai nuo lyties ir išsilavinimo

\begin{tabular}{||c|c|c|c|c|c|c|c||}
\hline \multirow{2}{*}{} & \multicolumn{2}{|c|}{ Taškų vidurkis \pm SN pagal lyti } & \multicolumn{4}{c|}{ Taškų vidurkis \pm SN pagal išsilavinimą } \\
\cline { 2 - 8 } & $\mathbf{M}$ & $\mathbf{V}$ & $\mathbf{p}$ & Vidurinis & Aukštasis neuniversitetinis & Aukštasis universitetinis & $\mathbf{p}$ \\
\hline FP & $40,54 \pm 13,99$ & $42,46 \pm 15,43$ & 0,217 & $44,36 \pm 11,87$ & $36,71 \pm 15,25$ & $39,84 \pm 15,73$ & 0,323 \\
\hline FP kontr. & $18,83 \pm 1,17$ & $18,43 \pm 2,01$ & 0,762 & $18,61 \pm 1,78$ & $19,43 \pm 0,98$ & $18,63 \pm 1,42$ & 0,375 \\
\hline Happé & $13,48 \pm 1,95$ & $14,00 \pm 1,37$ & 0,335 & $13,72 \pm 1,73$ & $13,00 \pm 1,91$ & $13,72 \pm 1,79$ & 0,534 \\
\hline
\end{tabular}

SN - standartinis nuokrypis, M - moterys, V - vyrai, p - p reikšmė, FP - Faux pas atpažinimo testo faux pas istorijų įvertinimas, FP kontr. - Faux pas atpažinimo testo kontrolinių istorijų ịvertinimas, Happé - Happé keistų istorijų testo įvertinimas

mieji; mažiausiai surinkta 14 taškų (3 asmenys). 23 asmenys surinko maksimalų Happé keistų istorijų testo įvertinimą (Happé), mažiausias įvertinimas - 10 taškų (4 asmenys).

Faux pas atpažinimo testo kiekvienos faux pas ir kontrolinès istorijos ịvertinimai apibendrinti 2 lentelèje. Ge- riausiai faux pas aptiktas (t. y. ị pirmą klausimą atsakyta teigiamai) 2-oje (97 asmenys) ir 4-oje (90 asmenų), blogiausiai - 13-oje (31 asmuo) ir 18-oje (55 asmenys) istorijose. Vertinant kontrolines istorijas, visi tiriamieji teisingai atmetė faux pas (t. y. ị pirmą klausimą atsakẻ neigiamai) 3-ioje, 10-oje ir 19-oje istorijose. Blogiausiai faux pas at- 
mestas 9-oje (85 asmenys), 6-oje ir 20-oje (po 87 asmenis) istorijose.

Happé keistų istorijų testo atskirų istorijų ịvertinimai pateikti 3 lenteleje. Geriausiai suprastos 5-a (vidurkis $1,92 \pm 0,27$ ) ir 2 -a (vidurkis - 1,88 $\pm 0,41$ ), blogiausiai 3 -ia (vidurkis - 1,45 $\pm 0,50$ ) ir 7-a (vidurkis - 1,62 $\pm 0,49$ ) istorijos.

Ivertinimų skirtumai tarp lyčių ir skirtingą išsilavinimą turinčių asmenų pateikti 4 lentelèje. Visų testų ịvertinimai tarp lyčių statistiškai reikšmingai nesiskyrè. Taip pat nenustatyta statistiškai reikšmingų įvertinimų skirtumų tarp skirtingo išsilavinimo asmenų.

Vertinant testų rezultatus pagal tiriamųjų amžių, nenustatyta statistiškai reikšmingos Faux pas atpažinimo testo faux pas istorijų $(\mathrm{r}=-0,092, \mathrm{p}=0,362)$, kontrolinių istorijų $(r=-0,001, p=0,989)$ ir Happé testo $(r=0,042, p=0,676)$ rezultatų koreliacijos su amžiumi.

\section{Testu patikimumas}

Didžiausia Cronbach $\alpha$ koeficiento reikšmė nustatyta Faux pas atpažinimo testo faux pas istorijoms $(0,815)$, kiek mažesnè - Happé keistų istorijų testo istorijoms $(0,708)$. Abu įverčiai rodo pakankamą testų vidinį nuoseklumą. Mažiausias Cronbach $\alpha$ koeficientas $(0,426)$, apskaičiuotas Faux pas atpažinimo testo kontrolinėms istorijoms, rodo nepakankamą šios Faux pas atpažinimo testo dalies vidinị nuoseklumą.

Apskaičiuota Faux pas atpažinimo testo faux pas istorijų intraklasinio koreliacijos koeficiento reikšmè yra 0,996, o Happé keistų istorijų testo - 0,911. Šie rezultatai rodo pakankamai gerą testų vertinimo patikimumą. Faux pas atpažinimo testo kontrolinių istorijų intraklasinis koreliacijos koeficientas nebuvo skaičiuojamas, kadangi šios testo dalies vertinimas yra objektyvus ir nuo vertintojo nepriklauso.

\section{Matavimų pagrịstumas}

Ekspertai, atidžiai peržiūrèję testus ir išanalizavę dalyvių pastebejjimus, nusprendè, kad istorijos yra aiškios, o pateikiami klausimai - pagrịsti ir pakankami, kad būtų ịvertintas tiriamojo supratimas apie veikejų poelgius ir jausmus. Išanalizavus literatūros duomenis, sutarta, kad abu testai gali įvertinti tiek pažintinę, tiek afektinę MT funkcijas. Taigi abiejų testų išorinis ir turinio pagrịstumas buvo įrodyti.

Vertinant testų tarpusavio koreliaciją, nustatyta statistiškai reikšminga, bet silpna teigiama koreliacija tarp Happé testo ir Faux pas atpažinimo testo faux pas istoriju ivertinimo $(\mathrm{r}=0,355, \mathrm{p}=0,045)$. Visgi tarp Faux pas atpažinimo testo faux pas istorijų ir kontrolinių istoriju $(\mathrm{r}=0,033, \mathrm{p}=0,745)$ bei Happé testo ir Faux pas atpažinimo testo kontrolinių istorijų $(\mathrm{r}=0,109, \mathrm{p}=0,282)$ rezultatų koreliacijos nustatyta nebuvo. Taigi konvergentinio konstrukcijos pagrįstumo kriterijų atitinka Faux pas atpažinimo testo faux pas istorijų dalis ir Happé keistų istorijų testas.

\section{REZULTATU APTARIMAS}

\section{Faux pas atpažinimo testas}

Duomenys lyginti su 2012 m. Söderstrand ir Almkvist švediškai bei 2016 m. Faísca ir bendraautorių portugališkai kalbančioms populiacijoms pritaikytų Faux pas atpažinimo testo versijų validizacijos rezultatais. İ švediškos versijos tyrimą įtraukti 68 asmenys (36 moterys ir 32 vyrai) nuo 18 iki 49 metų, į portugališkos - 200 asmenų (125 moterys ir 75 vyrai) nuo 18 iki 60 metų amžiaus $[21,22]$.

Gauti mažesni istorijų su faux pas įverčiai nei švedų tyrimo metu: švedų FP vidurkis - 49,20 \pm 8,38 (mūsų tyrimo $-41,25 \pm 14,49$ ) taško, be to, jų tyrimo metu buvo surinktas maksimalus ịvertinimas (60 taškų) [21]. Visgi mūsų tyrimo FP vidurkis yra daug didesnis, nei apskaičiuotas portugalų tyrime $(29,86 \pm 13,35)$ [22]. Gautas kontrolinių istorijų įverčių (FP kontr.) vidurkis - 18,68 \pm 1,54 taško yra palyginamas su švedų $(19,20 \pm 1,55)$ ir portugalų $(18,51 \pm 2,35)$ tyrimų rezultatais. Kaip ir kituose, mūsų tyrime taip pat buvo priartèta prie „lubų“ efekto (angl. ceiling effect) [21, 22].

Geriausiai faux pas aptinkamas 2-oje istorijoje (97,0\% mūsų tyrime ir 86,5 \% validizuojant portugališką versiją), blogiausiai - 13-oje istorijoje (31,0 \% ir 43,0 \%). Analizuojant kontrolinių istorijų rezultatus, visi dalyviai teisingai atmeté faux pas 3-ioje, 10-oje ir 19-oje istorijose; portugalų tyrime geriausiai atmesta 10-oje, 17-oje, 19-oje istorijose (97,0\% tiriamujų) [22].

Faux pas atpažinimo testo rezultatų skirtumų tarp lyčių nenustatėme. Nors kitų šalių tyrimuose kontrolinių istorijų įvertinimas tarp lyčių taip pat nesiskyrè, buvo rasta, kad moterys reikšmingai geriau nei vyrai atsako ị istorijų su faux pas klausimus [21,22]. Testo autoriai taip pat nurodo aukštesnius moteriškos lyties įvertinimus [16]. Remiantis Baron-Cohen, vieno iš Faux pas atpažinimo testo kūrèjų, teorija, moterys, mėgindamos nuspèti kito žmogaus elgesị, labiau linkusios ị mėginimą suprasti jo psichinę būseną, o vyrai - i ịprastų elgesio modelių sisteminimą ir naudojimą [23]. MT tinklo aktyvumo skirtumai tarp lyčių buvo įrodyti eksperimentiniais tyrimais [24]. Taigi, vertinant MT funkcijas, rekomenduojama atsižvelgti į tiriamojo lytị.

Negavome ir reikšmingos tiriamujų amžiaus bei testo ịvertinimų koreliacijos. Tai atitinka analizuojamų validizacijų rezultatus [21, 22]. Visgi, remiantis Henry ir bendraautorių metaanalize, vyresni žmonės prasčiau atlieka MT funkcijas tiriančias užduotis [25]. Nors įrodyta, kad tai nèra su amžiumi susijusio kitų pažintinių funkcijų (pvz., atminties, vykdomųjų funkcijų, informacijos apdorojimo greičio) deficito pasekmé, tikslios MT funkcijų blogejjimo priežastys kol kas nežinomos [26].

Nenustatyta reikšmingų testo ịvertinimų skirtumų tarp skirtingo išsilavinimo asmenų. Švedų tyrime taip pat nerasta rezultatų priklausomybės nuo išsilavinimo, o portugalų - nustatyta mažo efekto dydžio teigiama priklausomybė [21, 22]. Nors Li su bendraautoriais nurodo, kad aukštesnị išsilavinimą turintys vyresni (70-79 metų) tiriamieji Faux pas atpažinimo testą atlieka geriau nei turintys 
žemesnị išsilavinimą, išsamių tyrimų priklausomybès ryšio įvertinimui trūksta [27].

Gauta Faux pas atpažinimo testo faux pas istorijų Cronbach $\alpha$ koeficiento reikšmé yra 0,815 ir atitinka apskaičiuotas švedų $(0,905)$ ir portugalų $(0,816)$ tyrimuose $[21,22]$. Vidini šios testo dalies nuoseklumą galima laikyti geru. Kontrolinių istorijų dalies Cronbach $\alpha$ koeficiento reikšmė $(0,426)$, taip pat atitinkanti švedų $(0,415)$ ir portugalų $(0,568)$ tyrimų rezultatus, rodo nepakankamą šių istorijų vidinį nuoseklumą [21,22]. Apskaičiuota Faux pas atpažinimo testo faux pas istorijų intraklasinio koreliacijos koeficiento reikšmè $(0,996)$ prilygsta švedų tyrimo rezultatui $(0,916)$ (validizuojant portugališką versiją, šis koeficientas neskaičiuotas) [21]. Taigi, Faux pas atpažinimo testo faux pas istorijos turi aukštą patikimumo lygi, o kontrolinès istorijos šio kriterijaus neatitinka.

Remiantis ekspertų nuomone, visas testas atitinka išorinio ir turinio pagristumo kriterijus. Kadangi faux pas istorijų rezultatas reikšmingai koreliuoja su tas pačias sritis vertinančiu Happé keistų istorijų testu ( $\mathrm{r}=0,355$, $p=0,045)$, irodytas konvergentinis konstrukcijos pagrịstumas. Chen ir bendraautoriai taip pat rado reikšmingą teigiamą šių ịverčių koreliaciją $(r=0,290, p<0,05)$ [28]. Kontrolinių istorijų rezultatas reikšmingai nekoreliavo nei su faux pas istorijų, nei su Happé keistų istorijų testo rezultatais. Validizuojant švedišką versiją, apskaičiuota reikšminga neigiama kontrolinių ir faux pas istorijų koreliacija $(\mathrm{r}=-0,355, \mathrm{p} \leq 0,001)$. Nors tai sunku paaiškinti, bet galimai geras gebejjimas pastebėti nemalonias situacijas sąlygoja polinki i cer stiprią bet kokios bendravimo formos analizę ir reakciją i ją [21]. Ryšio tarp kontrolinių istorijų ir Happé keistų istorijų testo ịverčių analizès literatūroje nepavyko rasti, todèl Faux pas atpažinimo testo kontrolinių istorijų konvergentinis konstrukcijos pagrịstumas neįrodytas.

Testo istorijos su faux pas pasižymi geru patikimumu ir pagrịstumu, todèl yra naudotinos kasdieneje praktikoje. Kontrolinių istorijų psichometrinės savybės yra diskutuotinos, todèl jų naudojimo vertė abejotina, o rezultatai (ypač sveikų žmonių) turètų būti vertinami apdairiai. Visgi Faísca ir bendraautoriai teigia, kad šios testo dalies rezultatai gali būti naudingi vertinant MT deficito sunkumą [22].

\section{Happé keistų istorijų testas}

Testo rezultatai lyginti su $2017 \mathrm{~m}$. Shahrivar ir bendraautorių persiškai kalbančiai populiacijai pritaikytos Happé keistu istoriju testo versijos validizacijos duomenimis. I persiškos versijos tyrimą îtraukti 398 8-11 metu asmenys (202 mergaitės ir 192 berniukai) [29]. Rezultatų lyginimo pagrįstumas gali būti diskutuotinas, kadangi tiksliai nežinoma, kada MT nustoja vystytis. Westby ir bendraautoriai teigia, kad funkcijos galutinai susiformuoja iki 8-12 metų, remiantis kitais autoriais, jos tobuleja visą gyvenimą [18, 30]. Vis dèlto tai vienintelè prieinama angliška šio testo validizacijos versija.

Gautas testo ịverčių vidurkis $(13,67 \pm 1,77)$ yra gerokai didesnis nei Shahrivar ir bendraautorių tyrime
$(7,93 \pm 2,72)$ [29]. Kadangi nebuvo galima atmesti amžiaus itakos šiam skirtumui, rezultatas palygintas su Perez-Zapata ir bendraautorių tyrimo, îtraukusio 100 sveikų suaugusių asmenų (amžiaus vidurkis - 19,64 metų), duomenimis. Šio tyrimo rezultatai (testo ịvertinimų vidurkis - 14,16 $\pm 0,21$ ) gali būti prilyginami mūsų apskaičiuotiems įverčiams [31].

Atliekant persiškos versijos validizaciją, geriausiai suprasta 5-a istorija (vidurkis - 1,67 $\pm 0,69$ ). Nors 4-os istorijos įvertinimo vidurkis $(0,53 \pm 0,65)$ yra mažiausias, rečiausiai 2 taškais ịvertinta $(n=13)$, t. y. visiškai teisingai interpretuota, 3-ia istorija [29]. Tai atitinka mūsų duomenis, todèl galime teigti, kad lengviausiai šioje užduotyje įžvelgiamas „baltas” melas, o sunkiausiai - apgaulè. Visgi 6-os istorijos, kurioje taip pat užkoduotas „baltas” melas, ìverčiai nèra tokie geri kaip 5-os istorijos, todèl jos galimai vertina ne visai tą pačią sritị.

Reikšmingų testo rezultatų skirtumų tarp lyčių nenustatėme, nors Shahrivar ir bendraautoriai apskaičiavo, kad mergaitès užduotị atlieka geriau nei berniukai [29]. Vertinant literatūros duomenis, rezultatai yra nevienareikšmiški, todèl lyties įtaka šio testo atlikimui išlieka neaiški [32, 33]. Visgi, remiantis jau aptartais MT skirtumais tarp vyrų ir moterų, vertinant testo rezultatus derètų atsižvelgti ị tiriamojo lyti.

Neradome ir reikšmingos amžiaus bei išsilavinimo itakos keistų istorijų užduoties rezultatams, nors Cavallini ir bendraautoriai, tirdami sveikus 20-82 metų amžiaus asmenis, nustatė reikšmingą neigiamą koreliaciją tarp testo ivverčių ir amžiaus. To paties tyrimo rezultatai rodo, kad aukštesnio išsilavinimo asmenys testą atlieka reikšmingai geriau nei žemesnio išsilavinimo tiriamieji [34]. Šių veiksnių reikšmė MT funkcijoms aptarta ankstesnèse dalyse.

Apskaičiuota didesnè Cronbach $\alpha$ koeficiento reikšmė $(0,708)$ nei Shahrivar ir bendraautorių tyrimo metu $(0,510)$ [29]. Kitų tyrimų duomenimis, testo vidinis nuoseklumas gali būti puikus ir Cronbach $\alpha$ koeficiento reikšmė siekti net 0,953 [35]. Intraklasinio koreliacijos koeficiento reikšmè $(0,911)$ prilyginama kitu autorių, kriterijų vertinusių kitu metodu (Koheno kapa (angl. Cohen's kappa) - 0,970), rezultatams (validizuojant persišką versiją, šie koeficientai neskaičiuoti) [36], taigi vertinimo patikimumas taip pat aukštas. Ekspertų nuomone, testas atitinka išorinio ir turinio pagrįstumo kriterijus. Rezultatų koreliacija su Faux pas atpažinimo testo įverčiais ir konvergentinis konstrukcijos pagricstumas aptarti ankstesnèse dalyse. Irodytas geras Happé keistų istorijų testo patikimumas ir matavimų pagrịstumas, todèl rekomenduojamas jo naudojimas objektyviam MT funkcijų įvertinimui.

\section{IŠVADOS}

Faux pas atpažinimo ir Happé keistų istorijų testai yra pritaikyti lietuviškai kalbančiai populiacijai. Abu instrumentai gali būti naudingi vertinant socialines pažintines funkcijas. Ateityje reikalinga ir kitų testų, atskirai įvertinančių MT sritis, adaptacija. 


\section{Literatūra}

1. American Psychiatric Association. Diagnostic and statistical manual of mental disorders. $5^{\text {th }}$ ed. Arlington, VA: American Psychiatric Association, 2013; 947. https://doi.org/10.1176/ appi.books. 9780890425596

2. Fiske ST, Taylor SE. Social cognition. $2^{\text {nd }}$ ed. New York: McGraw-Hill, 1991; 717.

3. Phillips LH, Scott C, Henry JD, Mowat D, Bell JS. Emotion perception in Alzheimer's disease and mood disorder in old age. Psychol Aging 2010; 25(1): 38-47. https://doi.org/ 10.1037/a0017369

4. Brüne M, Abdel-Hamid M, Lehmkämper C, Sonntag C. Mental state attribution, neurocognitive functioning, and psychopathology: what predicts poor social competence in schizophrenia best? Schizophr Res 2007; 92(1-3): 151-9. https://doi.org/10.1016/j.schres.2007.01.006

5. Sodian B, Kristen S. Theory of mind. In: Glatzeder B, Goel V, Müller A, eds. Towards a theory of thinking: building blocks for a conceptual framework. Berlin, Heidelberg: Springer, 2010; 189-201. https://doi.org/10.1007/ 978-3-642-03129-8_13

6. Adolphs R. The neurobiology of social cognition. Curr Opin Neurobiol 2001; 11(2): 231-9. https://doi.org/10.1016/ S0959-4388(00)00202-6

7. Decety J, Jackson PL. The functional architecture of human empathy. Behav Cogn Neurosci Rev 2004; 3(2): 71-100. https://doi.org/10.1177/1534582304267187

8. Barak B, Feng G. Neurobiology of social behavior abnormalities in autism and Williams syndrome. Nat Neurosci 2016; 19(6): 647-55. https://doi.org/10.1038/nn.4276

9. Castelli F, Frith C, Happé F, Frith U. Autism, Asperger syndrome and brain mechanisms for the attribution of mental states to animated shapes. Brain J Neurol 2002; 125(Pt 8): 1839-49. https://doi.org/10.1093/brain/awf189

10. Bentall RP, Rowse G, Shryane N, Kinderman P, Howard R, Blackwood N, et al. The cognitive and affective structure of paranoid delusions: a transdiagnostic investigation of patients with schizophrenia spectrum disorders and depression. Arch Gen Psychiatry 2009; 66(3): 236-47. https://doi.org/ 10.1001/archgenpsychiatry.2009.1

11. Péron J, Vicente S, Leray E, Drapier S, Drapier D, Cohen R, et al. Are dopaminergic pathways involved in theory of mind? A study in Parkinson's disease. Neuropsychologia 2009; 47(2): 406-14. https://doi.org/10.1016/ j.neuropsychologia.2008.09.008

12. Gregory C, Lough S, Stone V, Erzinclioglu S, Martin L, Baron-Cohen S, et al. Theory of mind in patients with frontal variant frontotemporal dementia and Alzheimer's disease: theoretical and practical implications. Brain J Neurol 2002; 125(Pt 4): 752-64. https://doi.org/10.1093/brain/awf079

13. Stone VE, Baron-Cohen S, Calder A, Keane J, Young A. Acquired theory of mind impairments in individuals with bilateral amygdala lesions. Neuropsychologia 2003; 41(2): 209-20. https://doi.org/10.1016/S00283932(02)00151-3

14. Wimmer H, Perner J. Beliefs about beliefs: representation and constraining function of wrong beliefs in young children's understanding of deception. Cognition 1983; 13(1): 103-28. https://doi.org/10.1016/0010-0277(83)90004-5

15. Baron-Cohen S, Wheelwright S, Hill J, Raste Y, Plumb I. The "Reading the Mind in the Eyes" Test revised version: a study with normal adults, and adults with Asperger syndrome or high-functioning autism. J Child Psychol Psychiatry 2001; 42(2): 241-51. https://doi.org/10.1111/1469-7610.00715
16. Baron-Cohen S, O'Riordan M, Stone V, Jones R, Plaisted K. Recognition of faux pas by normally developing children and children with Asperger syndrome or high-functioning autism. J Autism Dev Disord 1999; 29(5): 407-18. https://doi.org/10.1023/A:1023035012436

17. Happé FGE. An advanced test of theory of mind: understanding of story characters' thoughts and feelings by able autistic, mentally handicapped, and normal children and adults. J Autism Dev Disord 1994; 24(2): 129-54. https://doi.org/ 10.1007/BF02172093

18. Westby C, Robinson L. A developmental perspective for promoting theory of mind. Top Lang Disord 2014; 34(4): 362-82. https://doi.org/10.1097/TLD.0000000000000035

19. White S, Hill E, Happé F, Frith U. Revisiting the strange stories: revealing mentalizing impairments in autism. Child Dev 2009; 80(4): 1097-117. https://doi.org/10.1111/j.14678624.2009.01319.x

20. Litwin M. How to measure survey reliability and validity. Vol. 7. Thousand Oaks, CA: SAGE Publications, Inc., 1995; 96. https://doi.org/10.4135/9781483348957

21. Söderstrand P, Almkvist O. Psychometric data on the Eyes Test, the Faux Pas Test, and the Dewey Social Stories Test in a population-based Swedish adult sample. Nord Psychol 2012; 64(1): 30-43. https://doi.org/10.1080/19012276. 2012.693729

22. Faísca L, Afonseca S, Brüne M, Gonçalves G, Gomes A, Martins AT. Portuguese adaptation of a Faux Pas Test and a Theory of Mind Picture Stories Task. Psychopathology 2016; 49(3): 143-52. https://doi.org/10.1159/000444689

23. Baron-Cohen S. Empathizing, systemizing, and the extreme male brain theory of autism. Prog Brain Res 2010; 186: 167-75. https://doi.org/10.1016/B978-0-444-536303.00011-7

24. Adenzato M, Brambilla M, Manenti R, De Lucia L, Trojano L, Garofalo S, et al. Gender differences in cognitive Theory of Mind revealed by transcranial direct current stimulation on medial prefrontal cortex. Sci Rep 2017; 7(1): 1-9. https://doi.org/10.1038/srep41219

25. Henry JD, Phillips LH, Ruffman T, Bailey PE. A meta-analytic review of age differences in theory of mind. Psychol Aging 2013; 28(3): 826-39. https://doi.org/10.1037/a0030677

26. Bernstein DM, Thornton WL, Sommerville JA. Theory of mind through the ages: older and middle-aged adults exhibit more errors than do younger adults on a continuous false belief task. Exp Aging Res 2011; 37(5): 481-502. https://doi.org/10.1080/0361073X.2011.619466

27. Li X, Wang K, Wang F, Tao Q, Xie Y, Cheng Q. Aging of theory of mind: the influence of educational level and cognitive processing. Int J Psychol 2013; 48(4): 715-27. https://doi.org/10.1080/00207594.2012.673724

28. Chen K-W, Lee S-C, Chiang H-Y, Syu Y-C, Yu X-X, Hsieh C-L. Psychometric properties of three measures assessing advanced theory of mind: evidence from people with schizophrenia. Psychiatry Res 2017; 257: 490-6. https://doi.org/10.1016/j.psychres.2017.08.026

29. Shahrivar Z, Tehrani-Doost M, Khorrami Banaraki A, Mohammadzadeh A, Happé F. Normative data and psychometric properties of a farsi translation of the strange stories test. Autism Res 2017; 10(12): 1960-7. https://doi.org/10.1002/aur.1844

30. Miller SA. Theory of mind: beyond the preschool years. New York: Psychology Press, 2012; 264. https://doi.org/10.4324/ 9780203122730 
31. Perez-Zapata D, Slaughter V, Henry JD. Cultural effects on mindreading. Cognition 2016; 146: 410-4. https://doi.org/ 10.1016/j.cognition.2015.10.018

32. Ronald A, Viding E, Happé F, Plomin R. Individual differences in theory of mind ability in middle childhood and links with verbal ability and autistic traits: a twin study. Soc Neurosci 2006; 1(3-4): 412-25. https://doi.org/10.1080/ 17470910601068088

33. Devine RT, Hughes C. Silent films and strange stories: theory of mind, gender, and social experiences in middle childhood. Child Dev 2013; 84(3): 989-1003. https://doi.org/ 10.1111/cdev.12017

34. Cavallini E, Lecce S, Bottiroli S, Palladino P, Pagnin A. Beyond false belief: theory of mind in young, young-old, and old-old adults. Int J Aging Hum Dev 2013; 76(3): 181-98. https://doi.org/10.2190/AG.76.3.a

35. Velloso R de L, Duarte CP, Schwartzman JS. Evaluation of the theory of mind in autism spectrum disorders with the Strange Stories test. Arq Neuropsiquiatr 2013; 71(11): 871-6. https://doi.org/10.1590/0004-282X20130171

36. Kaland N, Callesen K, Møller-Nielsen A, Mortensen EL, Smith L. Performance of children and adolescents with Asperger syndrome or high-functioning autism on advanced theory of mind tasks. J Autism Dev Disord 2008; 38(6): 1112-23. https://doi.org/10.1007/s10803-0070496-8

\section{A. Jasionis, G. Jasionytė, R. Mameniškienė \\ THE ADAPTATION AND EVALUATION OF PSYCHOMETRIC PROPERTIES \\ OF THE LITHUANIAN VERSIONS OF THE FAUX PAS RECOGNITION AND STRANGE STORIES TESTS}

\section{Summary}

Background. One of the main subdomains of social cognitive functions, Theory of Mind (ToM), involves the ability to under- stand other people's thoughts, intentions, emotions, and predict their behaviour. ToM deficit is common in many neurological and mental disorders. So far, there have been no measures assessing ToM functions adapted to the Lithuanian-speaking population.

Objective. To translate and perform a linguistic and cultural adaptation of two ToM tests - the Faux Pas Recognition test and Happé Strange Stories test - to the Lithuanian-speaking population and to evaluate their psychometric properties.

Materials and methods. Both instruments were translated from English into Lithuanian and from Lithuanian into English. A total of 100 adult subjects were tested using Lithuanian test variants. The reliability and validity of the instruments were evaluated. Internal consistency was estimated by calculating the Cronbach $\alpha$ coefficient, the inter-rater reliability by the intraclass correlation coefficient, and the convergent construct validity by the Spearman correlation coefficient.

Results. The Cronbach $\alpha$ coefficient for the faux pas stories of the Faux Pas Recognition test was 0.815 , for the control stories 0.426 , and for the Strange Stories test 0.708 . The intraclass correlation coefficient of the faux pas stories of the Faux Pas Recognition test was 0.996, and that of the Strange Stories test was 0.911 . There was a statistically significant weak positive correlation between the Strange Stories test and the faux pas stories ratings $(r=0.355, p=0.045)$, but the control stories of the Faux Pas Recognition test did not statistically significantly correlate with the faux pas stories $(\mathrm{r}=0.033, \mathrm{p}=0.745)$ and Happé Strange Stories test $(r=0.109, p=0.282)$. The face and content validity of both instruments was good.

Conclusions. The Faux Pas Recognition test and Happé Strange Stories test are adapted to the Lithuanian-speaking population. Both instruments can be useful in evaluating social cognitive functions.

Keywords: theory of mind, social cognition, Faux Pas Recognition test, Happé Strange Stories test.

Gauta:

20200210

Priimta spaudai: 20200228 